\title{
Use Of New Media In The Local Press: Comparative Analysis Of Local Newspapers Websites In İzmir, Adana and Bursa
}

\author{
Berrin Kalsın, $\mathrm{PhD}^{\mathrm{i}}$ \\ Department New Media, Beykent University, İstanbul, Turkey
}

\begin{abstract}
Local press is defined as a press that serves to introduce and train the public and to provide the public opinion. Local press gives information about the cases happen around the region that it is published and it forms public opinion about the problems of that region. New communication technologies havehave an important role in the forming and enhancing the news contents in the media. Changeovers have occurred in the production, process and distributiondistribution of the news by developing the new media. On the other hand, Internet journalism used by many press institutions is occurredoccurred as a new concept in mass communication. National and local newspapers do not remain insensitive to this new mass communication and it attempts the Internet journalism. Firstly, pressed newspaper had been turned into Web sites as similar but later new application about the transferring the news to the reader have occurred when we look at this application about the transferring of the pressed newspaper to the Internet environment. In this study, the Internet websites if Adanaher from Adana, Olay from Bursa and Ege'nin Sesi from Izmir have been compared with each other. The form, content and interaction of these three newspapers have been discussed and the usage of social media and importance given to the local news have been analyzed.
\end{abstract}

Keywords: Local Press, New Media, Online Journalism

(C) 2014 Published by SSBFNET

\section{Introduction}

Local media is defined as the press which serves to inform the public and educate them and which also tries to mold public opinion. Local media gives information about the events that occurred in the immediate vicinity of the people of the region it is published and molds public opinion about the problems of that region. While national newspapers dealing with the events across the country and the world, local newspapers deal with the events occurred in theirs region and they have a limited audience because they are published only in a particular region.

In today's media age, the role of local media is rather great in the creation and enrichment of the news content of the new communication technologies. With the development of new media, there have been radical changes in the production, processing and distributing of the news. The internet has led to any new developments in our everyday lives. The most important of these developments is that internet is accepted as one of mass medium as a means of

\footnotetext{
${ }^{i}$ Department of New Media, Beykent University, Şişli., İstanbul, Turkey, Tel:+90 212 4441997(5059), Fax: +90 2128675066.
} 
receiving news. The internet giving access to all news by eliminating spatial boundaries is used in order to obtain local, national and international news.

On the other hand, the internet journalism used by many of the media organizations has emerged as a new phenomenon in the area of mass media. The world's first internet newspapers began publishing online in 1995. In America, newspapers such as The Washington Times and New York Times were transferred into web one for one. Again in 1995, in Europe, newspapers such as International Herald Tribune and Daily Mirror established their websites. In Turkey, the concept of internet journalism that started first with the Aktüel Magazine in 1995 continued with the newspaper Milliyet that regularly published online in 1996. National and local newspapers were forced to conform to this new form of mass media and stepped into internet journalism. The web pages of newspapers have become an important source of news that can interact with users and thus, feedbacks can be received. The news that contains text, audio and video together, that is known as multimedia, can take place on internet newspapers. Also, the newspapers can share many matters over their own social networking sites.

Internet newspaper that is known as transferring printed newspaper into online web has gradually reached a different structure due to the distinctive development of the internet. In short, new applications have emerged in conveying the news to the reader. Internet newspapers, as a source of news, make use of the social media in conveying the news and uses web links where all relevant information about the news can be found. In addition, because of its interactive features, they can easily communicate with the reader one-to-one.

In this sense, the study starts with discussion on the development of local press in Turkey and their present situation. Then, the research part of the study comes by providing information about new communication technologies and internet journalism. In the research part of the study, the internet home pages of the newspapers Adana Haber, Olay and Egenin Sesi from Adana, Bursa and İzmir respectively which are three major cities other than İstanbul and Ankara were comparatively studied. The issue of the study is which features these websites broadcasting online have. In this context, form and content features, being interactive and use of social networks of the newspapers mentioned were comparatively analyzed and the differences between them were revealed through tables.

\section{Literature Review}

\subsection{Local Press}

Local media is the press organ; that is published daily, weekly or at longer intervals in various parts of the country, particularly in the settlements outside the major cities which are provinces, districts and towns; that mentions the news, rumors and problems of the location in which it is published; that aims to mirror people's desires to those concerned. The pack that people want to get more information about the region they live in and that they intensively follow the sources that are providing information have made local media an alternative media. Local media contributes to strengthening of democracy in a region by serving as a kind of bridge between the administrators and those who are administrated as well as its task of providing information and public awareness. According to Doğan and Göker, local 
newspapers convey news from the perspectives of the readers, not from elite's. It is just like a market place where so many gossip and visions are shared at the same time. It is controlling the elites in the region and strengthens democracy by providing people's direct involvement. (Doğan ve Göker, 2009: 537) Individuals approach to the region, the culture and the community they live in with a closer sense of commitment and partnership. At this point, local press becomes the biggest assistant and source of reference of individuals in their local life.

There are newspapers published in foreign languages in the local scale before The Takvim-i Vakayi, 1831, which is recorded as the first common Turkish newspaper. That is, the first newspaper examples in Turkey are local newspapers. (Aydeniz, 2007: 10) Provincial newspaper laid the foundations of today's local journalism. The emergence of these newspapers is closely linked with the reform movement in many fields conceived under the name of The Tanzimat Reform Era which was tried to be realized in the territory of Ottoman Empire in the 19th century. The first major regulator in the local regions of the Ottoman was performed with the ordinance published on November 7th, 1864, by removing the state system and establishing the province system. Again, in order to serve the interests of the central government, local journalism is attached importance in the Ottoman period. Skipping to provincial system from the state system as a result of the reforms, it was decided to open a publishing house in every province. In these publishing houses, newspapers printed in foreign languages were published as well as Turkish. Provincial newspapers were incited by the desire to suppress the influence of Arabic periodicals that were everincreasing in number and were particularly aimed at Arabic people on the one hand, and the desire to compensate the separatist tendencies on the other hand. (Çı̆̆, 2007: 46)

The first provincial newspaper is the Hakikat Al Ahbar published by Fuat Pasha who was charged with suppressing the civil strife in Beirut in 1860. Another newspaper is the Tune newspaper published by Mithat Pasha in Rousse in 1865. One of the major provincial newspapers is the Trablusgarp newspaper published in Tripoli in 1866. These newspapers were followed by the Envar-1 Şarkiyye (1866) published in Erzurum, the Hüdavendigar (1869) published in Bursa, the Aydın (1869) published in İzmir. (Çı̆̆, 2007: 47-48)

In the Ottoman period, there has been a significant increase in the number of local newspapers with the declaration of the Second Constitutional Monarchy. However, as it is known, local journalism in Turkey has experienced the most important period in the period of War of Independence. This was necessary for the Anatolian people in terms of proceeding to the national independence struggle, attempting the propaganda activities in order to guide the public opinion in line with one idea, succeeding the Independence War and ensuring adequate public support. Therefore, Mustafa Kemal Pasha ensured the newspapers İrade-i Milliye and then Hakimiyet-i Milliye to be published in order to quickly convey the events occurred within the country during the days when Erzurum and Sivas Congresses and people's support and trust in those who initiated the national independence movement to the public opinion within and outside the country. (Gündüz, 2007: 91) The first major problem of local press began in the 1950s. New transport policies implemented by the Democratic Party between 1950s-1960s allowed the national media to make a day to day delivery to Anatolia. Therefore, this situation brought some difficulties for the local press. These local newspapers 
with poor printing techniques, pages deprived of photos and articles written in bad Turkish slowly began to lose power against the colored newspapers of the national press. (Erdem, 2007: 115)

The most important difference of local newspapers from the national ones stems from the distribution area of the newspaper. While the national newspapers handling events on a country and world basis, the local ones deals with the events occurred in towns or cities and the news texts addresses to this limited audience. (Erdem, 2007: 116). Local media's functions can be grouped in three main categories:

i. Within the framework of Manager-Managed relationship, publicizing public services properly is one of the functions of local press. In addition, inspection of the manager in behalf of the public and creation of public opinion are among the responsibilities of local press.

ii. With the announcement of the local government services in towns, ensuring the relationship between the local government and citizens is one of the most important functions of local press.

iii. The education function that is one of the functions of the mainstream press gains importance with its social identity in local press. Establishing the culture of democracy required in the reflection of the national will properly is among the most important functions of local press. (Gezgin, 2007: 177-178)

People living in areas where indigenisation is strong in every aspect can defend their rights more effectively. It can be seen that these people are one move ahead of the populations living in the areas where local press is not strong about democracy, human rights and freedoms. It is observed that, in the regions where local press is strong, the local people claims democracy, their individual rights and common rights as a community stronger. These people have the opportunity to express their wants and needs more comfortable and they can follow up their operation. Is is a fact that democracy gains power with the local units. With the realization of local democracy in a healthy way, the chance of democracy settlement will also increase across the country. (Gezgin, 2007: 193) It is a fact that democracy gains power with the local units. With the realization of local democracy in a healthy way, the chance of democracy settlement will also increase across the country. The institutions that will reflect the relationships of local governments to the people living in local areas are the local press organs. (Gezgin, 2007: 195)

Today, the local press has some problems such as primitive printing machines, newsprint supply, inability to take an equitable share from the advertising and announcement repository, shortage of professional staff, regional pages of the mainstream press, technical shortcomings, and tries to survive in spite of everything under these difficult circumstances. (Erdem, 2007: 115) The local press needs to obtain sufficient support and seriously to come to an effective position. This will extremely be useful for the areas where the local press organs are. Because, by means of these publications, the problems and requests of the area are voiced and the follow-up of the issue will be ensured. (Nalcığlu, 2007: 207). Today, there are still local newspapers deprived of even the most basic technological facilities in many cities of Anatolia against the national press operating in the giant media plazas equipped with the world-class latest technology many of which are in İstanbul. We can list the lack of qualified staff and the lack of wages among the biggest problems of local media. 


\subsection{New Communication Technologies and Online Journalism}

"Imagine a library that has 4925 newspapers from all over the world. Internet provides more news content than all the daily newspapers and most of it is free. It is not surprising that an estimated 359 million internet users resort to the internet to read the news. Surely, the internet offers lots of valuable information." ( J. V. Pavlik)

The 20th century in which important advances and inventions were experienced in the history of mankind has given its place to a new millennium. As is well known, the 19th century witnessed that the newspaper became a popular and common mass medium with the emergence of the concept of mass society. The 21 st century is likely to be a century in which electronic journalism becomes widespread. Seen from this perspective, in the 21 st century, a new model of society is mentioned especially for the developed western countries. A number of sociologists have proposed new concepts that will define this new model of society. For example, the definitions "the society beyond-industry" by Daniel Bell, "the electronic age" or "the information age" by McLuhan were defined. (Dağdaş, 2002: 254)

Today, the new communication mediums are called as the new media. The concept of new media is a concept put forward by the researchers who conducts social, psychological, economic, political and cultural studies in information and communication-based researches. However, the meaning mentioned in the 70s has expanded with the computer and internet technology that gained a terrific acceleration in the 90s and has reached a different size. (Dilmen, 2007: 114) According to another definition, the new media has a feature that has the ability to band together all the known different media. This is called as "multi-media". The coexistence of the media such as text, still images, moving images, audio creates this feature. (Dilmen, 2007: 115) According to Binark, the basic characteristics of the new media are as follows:

"The most prominent feature of the new media that separates it from the traditional media is that it has interactive and multimedia formats. Because they are based on digital coding system, they can transmit large amounts of information at the same time and has the opportunity for the user to give feedback. Thus, the straight-linear transmission of information turned into to be hypertext. The transactional feature of the new media provided the communication process with reciprocity and the opportunity of multilayer communication. Another converting feature of the transactional feature regarding the communication process is its development in the degree of being simultaneous in the communication time. This feature of the new media, compared to the traditional media, affects the role and participation of the user in the process of communication in various ways." (Binark, 2007: 21)

One of the results of the new communication technologies is that it is now easy to say what is mass communication or not. The boundary between the mass media and other forms of communication is no longer so far as it was. The most important development in these new communication technologies concerning the aspect of written press has been 
"electronic journalism". For example, the newspaper "USA Today" is presented to the reader by taking advantage of the benefits of communication technologies. Technologically, the "USA Today" sends its pages to regional publishers via satellite and these satellites are the ones which send the cable TV programs. In fact, the USA Today is similar to other mass medium in terms of content, rather than a traditional newspaper. Especially in underdeveloped and developing countries, the fact that the budget allocated to education and that the incentives for the press remain at a limited level have caused newspapers to be an expensive mass medium. In these countries where the purchasing power is already low, newspapers emerge as an expensive and unnecessary mass medium. (Dağdaş, 2002: 256-258)

With the rapid advance in communication technologies, newspapers have the opportunity to reach the reader in a new and different way as well as publishing traditional newspaper. Today, almost all electronic newspapers offer their broadcasts from their own service providers via internet. Newspapers created their own electronic newspaper pages in order to be able to convey the news they collect to more people from different groups. This new kind of journalism emerged as the newspapers started to publish on the internet is called electronic or virtual journalism. (Yücedoğan, 2002: 145).

It is indicated that internet journalism, in general, has passed through three periods. The journalists, in the first period, transferred the news they collect for their printed newspaper to their internet pages. In the second period, unique and different news content began to be produced for internet. In the third period, the interactive communication was provided instead of one-way communication. Traditional media sites that broadcast on the internet today correspond to one of the four groups that reflect these periods. According to Yolcu, while some internet sites stay in the first period, some progressed step by step and tried to keep pace with the increasing demands of the internet users. These four groups are as follows:

"Public relations site; No news broadcast. Programs, corners, general history, access, and news related to the institution are provided. The electronic facsimile; A more advanced and same newspaper with the printed version of the newspaper that is in PDF format and that fully reflects the page. Web version; Access to all the news of the newspaper is possible. There is little or no dynamic parts. The ads and classified ads are different. Parallel web operations; This uses the newspaper as a content provider and goes beyond it. There is an intense dynamic part, news updates are made in every minute. It is, in practice, just like an independent internet newspaper that made an intense content partnership. It is culturally different from the main newspaper. "(Yolcu, 2007: 444-445)

Today, an important group of people making use of internet consists of newspaper and journalists. Although journalism over the internet is not much different from the normal print journalism, the internet domain offers the journalists with a greater freedom and ease of operation. (Yücedoğan, 2002: 150). The Zaman newspaper was the first newspaper that entered into the internat domain on December2, 1995. Turkish Daily News, Türkiye, Milliyet, Fanatik in 1996, Hürriyet, Sabah, Akşam in 1997 are the newspaper published on the internet. Thus, in Turkey; a step has been taken into the type of journalism defined as online or virtual. (Değirmencioğlu, 2007: 480) 
The news in the new media can benefit from all of the available opportunities such as text, audio, video, graphic, animation and 360 degree video. These opportunities ensure journalists to convey their news in the most appropriate way without being limited by the methods of the old traditional media. Internet journalism has many advantages. For instance; according to Pavlik, audience participation is available on the internet. Because the internet is an active communication tool rather that a passive tool like traditional printing and publishing tool, the participation of the readers is higher online. (Pavlik, 2013:35). Being interactive constitutes one of the most important features of electronic journalism. Namely, the readers provide feedback by sending their thoughts and comments about the topic or the news on the page. There are many ways to achieve this. E-mail, forums and pages that allows user comments, chat rooms, programs that offers written, voice and video calls which are named as Messenger and internet dairies are among these tools. (Değirmencioğlu, 2007:481) Virtual newspapers gain a different view and function from the normal newspaper by creating a one-to-one interactive demand with the reader in order to measure the impact created by the content of the written news. The readers have the opportunity to communicate directly with the writer when they have a problem about the article they read thanks to the author's e-mail addresses. In addition, readers are provided with the opportunity to make a better comparison by following the same news from many different authors, columns and newspaper on the internet. (Yücedoğan, 2002: 148)

Internet newspaper readers can access to their newspapers whenever they want or wherever they are via the internet. These developments in the new communication technologies change the nature of the concepts of timeliness and proximity which are among the basic elements of newspaper journalism. For instance; for those who reached the fresh news of newspapers at early hours in the morning, there is no value of these news in the evening. The newsbreaks published in the newspaper broadcasting online can be delivered to the readers quickly during the day. (Değirmencioğlu, 2007, 481) With the emergence of the internet, people can read newspaper that are refreshed instantly, not daily. Moreover, the concept of time and space loses its meaning with this way of communication. People who forget to buy a newspaper or those who can't have time can read the web pages of any newspaper while they are doing their things on their computers. (Yücedoğan, 2002: 146)

"The content of the internet is dynamic. The content of the news is more fluent. This situation ensures the events and processes to be represented better in the real life. People want to receive news on-demand and at a real time. The audience does not want to wait the evening news of newspaper of the following day for the developments related to the breaking news. They want to know this instantly and want the information to be reflected in the press as quickly as possible and they can reach this vie the internet. Finally, the news in electronic and digital domain can be adapted or individualized in a way that is not possible in other media. In concern with the first four dimensions, this individualized nature of online journalists offers the audience with a more dependent, a more textual and a multi-dimension than stories within the letters of publishing and printing analog media." (Pavlik, 2013: 37-38) 
Internet newspapers offer new opportunities such as the ability to reach the breaking news quickly, online newspaper archives and access to the news in these archives to both the media domain and those who work in the media field (Yücedoğan, 2002: 146). The biggest problem of daily written media is distribution. The production costs in the traditional newspapers do not exist in internet publishing.

\section{Online Journalism and Local Media}

The flow of information increasing with globalization, in the words of Mc Luhan, has made the world a global village and the meaning attributed to local media and the need for it have begun to change. In today's media environment in which communication technologies started to develop, some events that have the qualification of being local reach the whole world and acquire the qualification of being a common problem. At this stage, in an environment where the communication is globalized, the fact that local media in Turkey has come co a different position by taking advantage of the benefits of communication technologies emerges as a necessity. (Değirmencioğlu, 2007:484).

Before anything else, the internet has changed the definition of local media. It has become mandatory to define the local media. For instance; the first criteria to determine whether a is local or not is that it is sold and read only in a certain city. However, along with the internet, local newspapers have become readable across the country and even all over the world. On the other hand, the opportunity to define by adhering the reachable limits has disappeared. This situation drove forward the content. In short, a newspaper is now local to the extent the issues it contains. In addition, the low cost has relieved the local media organizations. Thanks to the internet, the competition conditions of local media organizations and national media organization have come close this much. (Yolcu, 2007: 454) Local media began to assume a character that can reflect the sound of the region accurately and in an impartial way and that contributes to the formation of public opinion by transferring social, economic, cultural and political developments. The local media organization reach the information more quickly as the internet has become a part of our lives and the interactive information sharing started to become effective. E-mail, news groups, forums, databases and search engines assumed an important role in obtaining and sharing the information. The internet pages that forward the news and comments of our local media led to the strengthening of democratic participation by ensuring the problems of the local people to be expressed. (Değirmencioğlu, 2007:484)

The fact that local newspapers broadcast over the internet is quite important especially for the people of that region who live away from the city or the country. Thanks to the internet, geographic barriers are eliminated, so the citizens who are away from the city can easily receive the news about their region. They can easily and quickly learn actual events, spats or local features of the city where they were born and grew up thanks to the local newspaper published on the internet. This situation also means that the citizens living in the city can make their voices be heard by those who are away thanks to the publication of local newspaper on the internet. (Yolcu, 2007:454) In addition, the local media organizations that have limited financial resources can create a common news pool. An example of this is done by www.bianet.org. BIA makes available the news that happen in the regions of local media organizations and that 
may concern not only that region in the consequence for all the media organization by bringing together these news in a common pool using the internet domain. Thus, it saves the local media from being dependent on the news agencies and the news format of the mainstream media. (Yolcu, 2007: 455)

\section{The Comparative Analysis of the Websites of Local Newspapers Published in İzmir, Adana and Bursa}

In the analysis section of this study, the websites named www.adanahabergazetesi.com.tr, www.olay.com.tr and www.egeninsesi.com were examined between April 6-8, 2014. The home pages of the websites were compared in terms of form and content. In this way, the web pages chosen within the scope of the sample and the differences between them have been relieved. The websites that will be discussed were examined in terms of form and content and then they were compared in terms of interaction and their use of social networks. The comparison was made with the marking system. (+) means Yes, (-) means No.

Table 1: The Formal Properties of Sites

\begin{tabular}{|c|c|c|c|}
\hline & www.adanahabergazetesi.com.tr & www.olay.com.tr & www.egeninsesi.com \\
\hline Tag & + & + & + \\
\hline Accessibility & + & + & + \\
\hline $\begin{array}{l}\text { Home Page } \\
\text { Coherence }\end{array}$ & + & + & + \\
\hline $\begin{array}{l}\text { Harmony between } \\
\text { pages }\end{array}$ & + & + & + \\
\hline $\begin{array}{l}\text { Survey, message } \\
\text { board }\end{array}$ & + & - & - \\
\hline Official classified & + & + & - \\
\hline Visitor counter & - & - & - \\
\hline Membership & - & + & - \\
\hline Sitemap & - & - & - \\
\hline Site search & + & + & + \\
\hline Language selection & - & - & - \\
\hline Archive & - & + & - \\
\hline Link functionality & + & + & + \\
\hline News printouts & - & + & + \\
\hline Making home page & + & - & - \\
\hline FAQs & - & - & - \\
\hline Photo Gallery & + & + & - \\
\hline Video gallery & + & + & + \\
\hline Weather & - & + & + \\
\hline Exchange rates & - & + & + \\
\hline $\begin{array}{l}\text { Number of ads on } \\
\text { home page }\end{array}$ & 1 & 7 & 9 \\
\hline
\end{tabular}


Considering the formal features of the sites, in general, there is not any trouble reaching the site. The overview of the three websites is formed successfully. In addition, properties that should be on a website such as Tag, contact information, site search are available. On the other hand, visitor counter, sitemap and FAQs are included in all the three sites. This situation indicates that all the three sites are not detailed websites. It was observed that the websites of the newspapers Olay and Adana Haber are more useful compared to the newspaper Egenin Sesi. For example; while both sites have photo gallery and official classified, the newspaper Egenin Sesi seems to fall behind in terms of use. In addition, considering the number of ads on the home page, it is observed that the highest number of ads is on the website of Egenin Sesi. The newspaper Adana Haber took only one ads and gave contact information for advertising.

Table 2: Contextual Features of the Sites

\begin{tabular}{|l|l|l|l|}
\hline & www.adanahabergazetesi.com.tr & www.olay.com.tr & www.egeninsesi.com \\
\hline Breaking news & + & + & + \\
\hline $\begin{array}{l}\text { Regional } \\
\text { dispersion of the } \\
\text { news }\end{array}$ & - & + & + \\
\hline $\begin{array}{l}\text { Dispersion of the } \\
\text { news according to } \\
\text { the types }\end{array}$ & + & + & + \\
\hline $\begin{array}{l}\text { The number of } \\
\text { news on the home } \\
\text { page }\end{array}$ & $25-30$ & $15-25$ & $10-15$ \\
\hline $\begin{array}{l}\text { The number of } \\
\text { news links on the } \\
\text { home page }\end{array}$ & $50-60$ & $50-55$ & $110-120$ \\
\hline $\begin{array}{l}\text { Use } \\
\text { photographs in the } \\
\text { news }\end{array}$ & + & + & + \\
\hline RSS/XML & + & & - \\
\hline
\end{tabular}

When the pages of the newspapers in the online domain are evaluated, it is seen that each of the three websites has the features that they should have. It was found that breaking news and photos which are very important for these news are used and that the news were separated according to their types (world, politics, economy, magazine, agenda etc.). Another issue of interest is the difference of the number of news and links of the news on the home page. While the news rate on the online websites of the newspapers Olay and Adana Haber are closer, the number of news link of the website of the newspaper Egenin Sesi is almost doubled in number. Generally speaking, the fact that there are many news links of an online newspaper creates a positive situation. Because, when the readers enter the page of the newspaper, they are facing many news at the same time and within the area of interest, they can browse through the news without entering the sub pages. Therefore, this situation creates a positive situation in terms of both the overall image and contextual richness of the page. On the other hand, considering the weight given by the newspapers to local 
news, it was determined that Adana Haber includes the most local news in number and this means that the mission and vision of the newspaper is correctly determined. Because, the most important task expected from local newspapers is that they give weight to local news. In this way, they fulfill their own duties apart from national newspapers.

Table 3: Interactive Features of the Sites

\begin{tabular}{|c|c|c|c|}
\hline & www.adanahabergazetesi.com.tr & www.olay.com.tr & www.egeninsesi.com \\
\hline Contact link & + & + & + \\
\hline E-mail to the editor & + & + & + \\
\hline $\begin{array}{l}\text { E-mails of the } \\
\text { authors }\end{array}$ & + & + & + \\
\hline Feedback form & + & - & + \\
\hline $\begin{array}{l}\text { Comment box for } \\
\text { the news }\end{array}$ & + & + & + \\
\hline $\begin{array}{l}\text { News sharing } \\
\text { button }\end{array}$ & + & + & + \\
\hline $\begin{array}{l}\text { Adding e-mail } \\
\text { button }\end{array}$ & - & - & - \\
\hline
\end{tabular}

Being interactive for a newspaper is an important point. Especially the difficulties experienced in reaching the authors and the managers of the newspaper cause the target audience to move away from these media organs by creating a one-way communication. In this sense, considering the three websites we examine, it is seen that all the three sites work interactively. Especially in recent years, the comment made for the news are noteworthy and at this point is was found that the newspapers are functional.

Table 4: Use of Social Networks of the Sites

\begin{tabular}{|l|l|l|l|}
\hline & www.adanahabergazetesi.com.tr & www.olay.com.tr & www.egeninsesi.com \\
\hline Facebook & + & + & + \\
\hline Twitter & + & + & + \\
\hline
\end{tabular}

The widespread use of social networks has not been escaped from online newspapers' notice. Sharing the news by the reader takes place via Facebook or Twitter. It was determined that all the three websites examined have this function.

\section{Conclusion and Evaluation}

We can say that the internet which is one of today's most important mass mediums is one of the biggest revolutions that have been realized so far. The internet has developed and changed the communication of the people and societies living in the world with each other. 
Online journalism has a nature in which text, photographs, images, audio, music and animations that are referred to as the multimedia can be used. In this sense, today many local and national newspapers publish over the internet in addition to making traditional printed publications. In this way, they had the opportunity to reach many readers. In this respect, how effective the three local newspapers' web pages (Adana Haber, Olay, Egenin Sesi) are tried to be demonstrated. These sites were compared in terms of formal, contextual, interaction and use of social networks.

It was determined that the three newspapers compared are useful in terms of form and overall image. The integrity of the home page and functionality of the links are successful. On the other hand, many points that can be privileged and detail are included in the websites. It was determined that some links such as site map, language selection, visitor counter and FAQs do not exist.

When considering in the contextual sense, including the breaking news, separating the news according to their characteristics are available in each of the three sites. The feature of distinguishing the news only in the regional sense exists on the website of the newspaper Adana Haber and this is an indication of that the newspaper operates only regionally. At this point, it is not be wrong to say that the newspaper Adana Haber proceeds a more accurate way in terms of fulfilling its function. Because, it was determined that this newspaper have more local news in its website compared to the other two.

When the three online newspapers discussed here are examined in terms of being interactive and using social networks, it was found that all are functional. All the three newspaper use Facebook and Twitter and offers the opportunity to share the news in this way.

\section{References}

Aydeniz, H. (2007). Tarihsel ve Literal Açıdan Yerel Gazetecilik, Ed. Suat Gezgin, Türkiye'de Yerel Basın, İ.Ü. İletişim Fakültesi Yayınları, İstanbul, 10.

Binark, M. (2007). Yeni Medya Çalışmalarında Yeni Sorular ve Yöntem Sorunu, Ed. Mutlu Binark, Yeni Medya Çalışmaları, Dipnot Yayınları, Ankara, 21.

Çı̆̆, Ü. (2007). 19. Yüzyılda Osmanlı'da Gazetecilik Hareketleri: Takvim-i Vekayi'den Vilayet ve Özel Girişim Gazetelerine, Ed. Suat Gezgin, Türkiye'de Yerel Basın, İ.Ü. İletişim Fakültesi Yayınları, İstanbul, 46-48.

Dağdaş, E. (2002). Basında Ortaya Çıkan Yeni İletişim Teknolojilerinin Okuyucular Üzerindeki Etkileri, İ.Ü. İletişim Fakültesi Dergisi, Sayı: 14, 254-258.

Değirmencioğlu, G., (2007). Yeni İletişim Teknolojilerinin Yerel Basına Sunduğu Olanaklar ve Kocaeli Yerel Gazetelerinin İnternet Sayfaları Üzerine Bir Değerlendirme, Ed. Suat Gezgin, Türkiye'de Yerel Basın, İ.Ü. İletişim Fakültesi Yayınları, İstanbul, 480-484.

Dilmen, N. E., (2007). Yeni Medya Kavramı Çerçevesinde İnternet Günlükleri-Bloglar ve Gazeteciliğe Yansımaları, Marmara Illetişim Dergisi, Sayı:12, Cilt:1, 114-115.

Doğan, A. vd. (2009). Yerel Medya Çalışanlarının Meslek Etiğine Bakışı, Ed: Mustafa Yağbasan, Medya ve Etik Sетроzуити Bildiri Kitabı, 537. 
Erdem, B. N. (2007). 12 Eylül 1980 İhtilali’nin Yerel Basının Haber Seçimleri Üzerindeki Etkisi: Hakimiyet Gazetesi Örneği, Ed. Suat Gezgin, Türkiye'de Yerel Basın, İ.Ü. İletişim Fakültesi Yayınları, İstanbul, 115-116.

Gezgin, S. (2007). Türkiye'de Yerel Basın, Ed. Suat Gezgin, Türkiye'de Yerel Basın, İ.Ü. İletişim Fakültesi Yayınları, İstanbul, 177-195.

Gündüz, U. (2007). Kurtuluş Savaşı'nda Yerel Basının Rolü, Ed. Suat Gezgin, Türkiye'de Yerel Basın, İ.Ü. İletişim Fakültesi Yayınları, İstanbul, 91.

Nalcıoğlu, B. U. (2007). Türkiye'de Yerel Medya Çalışanları, Yerel Medyanın Sorunları ve Çözüm Önerileri, Ed. Suat Gezgin, Türkiye'de Yerel Basın, İ.Ü. İletişim Fakültesi Yayınları, İstanbul, 207.

Pavlik, J. V. (2013). Gazetecilik ve Yeni Medya, Çev: Müge Demir ve Berrin Kalsın, Siyasal Kitabevi, Ankara, 35-47.

Yolcu, Ö. (2011).Gazetelerin Basılı Sürümlerindeki Fotoğrafların Online Sürümlerindeki Fotoğraflarla Karşılaştırılması: Cinsiyet ve Mesleki Temsil Açısından, İ.Ü. İletişsim Fakültesi Dergisi, Sayı: 40, 444-455.

Yücedoğan, G. (2002). İnternet Haberciliği, İ.Ü. İletişim Fakültesi Dergisi, Sayı: 14, 145-150. 